\title{
ROSYJSCY OŚWIECENI WOBEC (NIE TYLKO) KULTURY AGRARNEJ (ANDRIEJ BOŁOTOW I CZASOPISMO „SIELSKIJ ŻYTEL”)
}

\author{
RUSSIAN ENLIGHTENED ON (BUT NOT ONLY) AGRICULTURE \\ (ANDREY BOLOTOV AND THE PERIODICAL “SELSKY ZHITEL”)
}

\author{
MAGDALENA DĄBROWSKA
}

\begin{abstract}
AвSTRACт. The article presents the periodical "Selsky zhitel" ("The Villager"), which was published by Andrey Bolotov in Moscow in 1778-1779. It was the first Russian private agricultural journal with its purpose, programme, structure and contents. Bolotov's activity and the history of the Russian agricultural journals in the $18^{\text {th }}$ and early $19^{\text {th }}$ century constitute an interpretive background.
\end{abstract}

Keywords: Andrey Bolotov, Enlightenment, agriculture, Selsky zhitel, The Villager Magdalena Dąbrowska, Uniwersytet Warszawski, Warszawa - Polska, m.dabrowska@uw.edu.pl ORCID ID: 0000-0002-4014-4725

Za sprawą wydanej w przekładzie Kai Natalii Sakowicz w 1991 roku książki Dmitrija Lichaczowa Poezja ogrodów. O semantyce stylów ogrodowo-parkowych Andriej Bołotow mógł zaistnieć w świadomości polskiego czytelnika jako znawca sztuki ogrodowej, niezwykle popularnej w jego czasach, twórca autobiograficznego tomu pod przywodzącym na myśl powieści awanturnicze tytułem Życie i przygody Andrieja Bołotowa, przez niego samego opisane dla swoich potomnych (Жизнь и приключения Андрея Болотова, описанные самим им дяя своих потомков; 1789-1816; wyd. t. 1-4, 1870-1873) oraz redaktor czasopisma „Ekonomiczeskij magazin” („Экономический магазин"; 1780-1789), które wypełniał własnymi i cudzymi (głównie autorów zagranicznych) spostrzeżeniami na ten temat [zob. Lichaczow 1991]. Co ciekawe, po lekturze książki Lichaczowa czytelnik jest skłonny kojarzyć Andrieja Timofiejewicza Bołotowa (ur. w 7[18].10.1738 r. we wsi Dworianinowo $\mathrm{w}$ guberni tulskiej, zm. tamże $4[16] .10 .1833 \mathrm{r}$.), prozaika, poetę, dramaturga, tłumacza i dziennikarza [zob. m.in.: Лазарчук 1988: 114-117; Ольшевская, Травников 2002: 16-17; Бердников, Серебряный 2002: 3541; Бердышев 1949; Бердышев 1988а; Бердышев 1988б; Любченко 1988], raczej z romantyzmem niż z oświeceniem, chociaż to na "długi wiek XVIII” przypadła główna część jego działalności. Do sformułowania takiego wnios- 
ku skłaniają zwłaszcza komentarze do opinii Bołotowa o zgromadzonych w ogrodach w Carskim Siole budowlach, uznanych przez niego za mało gustowne, oraz o wykorzystaniu w planowaniu ogrodów zasady „niespodzianki". W pierwszej kwestii Lichaczow pisał:

Bołotow [...] popełnił jednak błąd: „chińskie” i „tureckie” konstrukcje w Carskim Siole powstały jeszcze w czasach, kiedy park pejzażowy był utrzymany w połowie w stylu rokoka, a w połowie - w stylu romantyzmu; dla rokoka "chińczyzna" i „tureczyzna” (według wyrażenia Bołotowa) nie były przebrzmiałym wraz z modą wyrazem złego smaku, tylko pełnoprawnymi komponentami stylowymi, natomiast w czasach, kiedy powstawały jego Wspomnienia [tj. Życie i przygody... - M.D. (w opinii Władimira Łazariewa utwór ten nie jest jednak ani wspomnieniami, ani dziennikiem; Лазарев 1979: 141; por. Веселова 2002: 190-199)], stłoczenie w parku różnych budowli egzotycznych rzeczywiście należało już do „minionego etapu” sztuki ogrodowej [Lichaczow 1991: 217].

W drugiej sprawie badacz wypowiedział się następująco:

co to za «nowości» i do czego służą wyjaśnia [...] C.C.L. Hirschfeld, którego idee propaguje Bołotow na łamach swojego „magazynu ekonomicznego"; [...] „nowość” $\mathrm{i}$ „niespodzianka” to w gruncie rzeczy jedno i to samo, jeśli chodzi o ogrody romantyczne, dlatego też Hirschfeld w przekazie Bołotowa radzi stosować nie tylko „nowości”, ale i „niespodzianki” [Lichaczow 1991: 240, 241].

O Christianie C. L. Hirschfeldzie (1742-1792), oświeceniowym niemieckim teoretyku sztuki ogrodowej, Bołotow wspominał często zarówno w autobiografii, jak i w czasopiśmie. Sposób wyłożenia przez niego naczelnej zasady Hirschfelda przy komponowaniu ogrodu, polegającej na stopniowym odsłanianiu zwiedzającym jego kolejnych komponentów, przywiódł na myśl Lichaczowowi wiersz poety romantycznego Dmitrija Wieniewitinowa Gałązka, ujmujący przyrodę jako „podległą stałemu ruchowi, nietrwałą i ulotną" [Lichaczow 1991: 253]. Wkład Bołotowa w rozwój sztuki ogrodowej był w równym stopniu teoretyczny i praktyczny. Jego najważniejszą pracę teoretyczną na ten temat stanowił artykuł $O$ ogrodach prywatnych $i$ wtasnych (O садах приватных и частных), opublikowany w czasopiśmie „Ekonomiczeskij magazin” w 1787 roku; poza samą ,"teorią" prowadzenia ogrodu znalazły się w nim rozważania filozoficzne o życiu ludzkim, którego poszczególne etapy autor uznał za analogiczne do faz rozwojowych roślin: narodziny człowieka odpowiadają wykiełkowaniu rośliny, starość i śmierć - więdnięciu i rozkładowi, jeśli ograniczyć się do początku oraz końca i pominąć całe bogactwo faz pośrednich. Po Bołotowie zostały nie tylko opisy ogrodów, ale także ich szkice projektowe, o czym w kontekście jego inicjatyw w Bogorodicku Lichaczow pisał: 
[...] o ile początkowo [...] projektował regularne ogrody poprzez wykreślanie rysunków technicznych, to później, pracując przy ogrodach pejzażowych, zmienił system pracy - najpierw wymyślał widoki w naturze, a dopiero potem odtwarzał je w rysunku; [...] zadanie, jakie sobie wyznaczył, polegało na komponowaniu różnego rodzaju iluzyjnych widoków i efektów krajobrazowych [Lichaczow 1991: 198].

Położony w guberni tulskiej Bogorodick stał się najważniejszym miejscem ogrodniczej praktyki Bołotowa, w którym założył pierwszy w Rosji park pejzażowy. Miejscowe "regularne” ogrody przekształcił on w "nieregularne” pod wpływem wytycznych Hirschfelda. Po pobycie w Bogorodicku (17761797), związanym z zarządzaniem majątkiem Katarzyny II, Bołotow porzucił służbę państwową i wrócił do Dworianinowa, w którym tworzyły się jego poglądy na kulturę agrarną.

Projektowanie oraz urządzanie ogrodów nie jest wyłącznym tematem ani Życia i przygód Andrieja Bołotowa..., ani pisma „Ekonomiczeskij magazin”, niejedynego zresztą wydawnictwa periodycznego ukazującego się z udziałem omawianego autora. Na rozległość zainteresowań Bołotowa, wnikliwego obserwatora i kronikarza swoich czasów, ich kultury materialnej oraz duchowej, wskazał M. Siemiewski w przedmowie do pierwszego tomu Życia i przygód... w wydaniu z 1870 roku [Семевский 1870: III]. Ramy czasowe opisywanych w książce wydarzeń obejmują lata 1738-1793 (albo nawet 1738-1812, czego jednak wobec niezachowania się końcowych partii tekstu nie sposób potwierdzić), a poruszaną problematykę za Lidią A. Olszewską i Siergiejem N. Trawnikowem można scharakteryzować następująco:

[...] mowa jest o kształtowaniu się osobowości rosyjskiego ziemianina, o radościach wiejskiego życia, [...] harmonii człowieka z otaczającym światem; [...] pojawiają się barwne obrazy z życia na prowincji i w stolicy [...], portrety przedstawicieli różnych stanów, oceny rosyjskiego przemysłu i rolnictwa, nauki oraz sztuki" [Ольшевская, Травников 2002: 17].

Badacze ci nazywają Życie i przygody... dziełem "encyklopedycznym” [Ольшевская, Травников 2002: 17]. Lew Bierdnikow i Jurij Sieriebrianyj dostrzegają $\mathrm{w}$ nim panoramiczność ujęć oraz osadzenie poszczególnych wydarzeń w szerokim kontekście historyczno-kulturowym [Бердников, Серебряный 2002: 40]. „Ekonomiczeskij magazin” nie był jedynym czasopismem, w którego wydawaniu uczestniczył Bołotow. Za każdym razem udział ten miał inny charakter, poczynając od roli wydawcy, a skończywszy na współpracy, polegającej na przesyłaniu artykułów do czasopism kierowanych przez kogoś innego. W latach 1778-1779 był on więc wydawcą czasopisma "Sielskij żytel”" („Сельский житель”), którego swoistą kontynuację stanowił „Ekonomiczeskij magazin” (zgodnie z konwencją epoki tytuły czasopism 
były znacznie dłuższe, tu podane są w wersji skróconej). Do periodyków, które publikowały jego prace należały „Zapiski diejanij Imperatorskogo Wolnogo ekonomiczeskogo obszczestwa” („Записки деяний Императорского Вольного экономического общества”, 1802-1812) oraz „Ziemledielczeskij żurnał” („Земледельческий журнал” , 1821-1840). W kontekście działalności na polu czasopiśmienniczym należy wspomnieć o znajomości Bołotowa z Nikołajem Nowikowem, najwybitniejszej postaci rynku wydawniczego i księgarskiego oświeceniowej Rosji. „Nowikow - żarliwy głosiciel idei Oświecenia, przenikliwy satyryk; Bołotow - przykładny [...] gospodarz [majątków ziemskich - M.D.], [...] solidny pisarz, solidny obywatel, obawiający się (...) gruntownych przemian" - pisał o nich Władimir Łazariew [Лазарев 1979: 143-144], przyjmując za podstawę porównania stopień radykalizmu w ich poglądach. Ważniejsze jednak niż podkreślanie różnic między nimi w tym zakresie wydaje się wskazanie podobieństwa, polegającego na tym, że obaj wnieśli duży wkład w rozwój czasopiśmiennictwa specjalistycznego w Rosji, zorientowanego na określoną kategorię odbiorców i dostarczającego wiedzy fachowej z danej dziedziny. W przypadku Andrieja Bołotowa jest to wiedza z zakresu agronomii, rozumianej szeroko jako teoretyczna i praktyczna wiedza o rolnictwie wraz z wiadomościami o zarządzaniu majątkiem ziemskim.

Na osobne odnotowanie zasługuje twórczość literacka Andrieja Bołotowa. Jej początki sięgają przełomu lat 50. i 60 . XVIII wieku, kiedy autor przebywał w Königsbergu. Miasto to jest trzecim - obok Dworianinowa i Bogorodicka - miejscem, z którym był on związany [Антонов 1990]. Zbiór z 1761 roku (Памятная книжка, или Собрание различных нравоучительных правил) uznawany jest za jeden z najwcześniejszych przejawów sentymentalizmu w Rosji [Ольшевская, Травников 2002: 16]. Ponadto Bołotowa można zaliczyć do pierwszych przedstawicieli rosyjskiej literatury dla dzieci, którą reprezentowały jego sztuki dydaktyczne z okresu pobytu w Bogorodicku (Чecmoxban, 1779; Награжденная добродетель, 1781) oraz przede wszystkim Filozofia dla dziесі... (Детская философия, или нравоучительные разговоры между одною госпожою и ее детьми, сочиненные для поспешествования истинной пользе молодых людей) z lat 1776-1779, zapoznająca młodych czytelników z astronomią, fizyką, geografią, botaniką oraz innymi naukami przyrodniczymi [Ольшевская, Травников 2002: 16; por. m.in. Кудрявцева 2010].

Nawet pobieżny przegląd spuścizny Andrieja Bołotowa pozwala stwierdzić, że przyroda stanowi jej główny temat. Autor patrzy na nią oczami bądź filozofa, jak - jeśli przywołać dzieła dotychczas niewymienione - w Listach o pięknie natury (Письма о красотах натуры) [Болотов 1993: 133-344], bądź przyrodoznawcy i specjalisty z zakresu rolnictwa, jak w pracach Opis wykorzystywanych w gospodarstwie pożytecznych wynalazków (Описание используемых в хозяйстве полезных изобретений) і Rady dotyczace hodowli bydta (Onытные 
замечания, относящиеся к скотоводствy), otwierających serię jego publikacji w pismach - pierwsza - „Zapiski diejanij Imperatorskogo Wolnogo ekonomiczeskogo obszczestwa” [Болотов 1803: 22-28] oraz - druga - „Ziemledielczeskij żurnał" [Болотов 1822: 109-113]. Obie perspektywy często łączyły się ze sobą. "Koncepcja filozoficzna Bołotowa zawierała wezwanie do harmonii między człowiekiem i przyrodą" - pisał Aleksandr K. Demichowski [Демиховский 1993: 132]. Aleksander Berdyszew określił Bołotowa mianem „pierwszego rosyjskiego uczonego-agronoma” [Бердышев 1949], „założyciela rosyjskiej nauki rolniczej" [Бердышев 1988б].

Prekursorska rola Nowikowa i Bołotowa w dziejach rosyjskiego czasopiśmiennictwa specjalistycznego polegała na tym, iż Nikołaj Nowikow założył pierwsze czasopisma dla kobiet („Модное ежемесячное издание, или Библиотека для дамского туалета”, 1779) i dla dzieci („Детское чтение для сердца и разума", 1785-1789), zaś Andriej Bołotow - pierwsze pismo rolnicze, którym był moskiewski „Sielskij żytel” z lat 1778-1779. Określenie go mianem "pierwsze rosyjskie czasopismo rolnicze" wymaga, po pierwsze, doprecyzowania w postaci dodania słowa "prywatne", oraz, po drugie, przywołania dwóch innych periodyków oświeceniowych. Chodzi o wydawane (z przerwami) w latach 1765-1775 „Trudy Wolnogo ekonomiczeskogo obszczestwa” („Труды Вольного экономического общества”), pierwszy rosyjski periodyk, w którym była poruszana problematyka rolnicza, oraz „Sankt-Peterburgskoje jeżeniedielnoje soczinenije” („Санкт-Петербургское еженедельное сочинение"), wydawane przez Augusta Wicmana równolegle z pismem "Sielskij żytel'” (od maja do października 1778 roku), ale nie w Moskwie, lecz w Petersburgu, również oświetlające tę tematykę [Акопов 1986: 80-90]. Jeśli „Sielskij żytel” był pierwszym prywatnym moskiewskim czasopismem rolniczym, to „Sankt-Peterburgskoje jeżeniedielnoje soczinenije" zapisało się jako pierwszy prywatny petersburski periodyk o tym profilu. Powstanie wszystkich wymienionych czasopism, a także pisma „Ekonomiczeskij magazin", przypadło na najwcześniejszy okres rozwoju specjalistycznych wydawnictw periodycznych w Rosji, który przyniósł również pierwsze czasopisma medyczne i techniczne, a także obecność tekstów o tematyce specjalistycznej w periodykach ogólnoinformacyjnych.

Powyższe wstępne rozważania można zakończyć dwiema uwagami, dotyczącymi - jedna - tendencji rozwojowych czasopiśmiennictwa doby Oświecenia oraz - druga - miejsca i roli Bołotowa w ówczesnych kręgach intelektualnych. W wydawnictwach periodycznych drugiej połowy XVIII stulecia dawały o sobie znać dwa zjawiska: ich redaktorzy stawiali sobie za cel wyposażenie czytelników bądź w ogólną wiedzę o świecie, reprezentującą rozmaite dziedziny i dotyczącą zarówno przeszłości, jak i współczesności, bądź w wiedzę specjalistyczną z jednej albo kilku dyscyplin pokrewnych. W drugim przypadku 
wiedza teoretyczna miała iść w parze z praktyczną. Ze swoimi zainteresowaniami sztuką ogrodową oraz problemami uprawy roli i hodowli zwierząt gospodarskich, a także szeroko rozumianym zarządzaniem majątkiem ziemskim Bołotow „wpisywał się" w swoją epokę i może być porównywany z innymi jej przedstawicielami, by wymienić choćby - jeśli chodzi o sztukę ogrodową - Nikołaja Lwowa. Pisząc o sztuce ogrodowej oraz agronomii, nie sposób nie wspomnieć również o Katarzynie II, inicjatorce, po pierwsze, upowszechniania w Rosji wiedzy o zagranicznych traktatach z zakresu ogrodnictwa [Веселова 2008: 333-345] oraz, po drugie, założenia Wolnego Towarzystwa Ekonomicznego, jednego z najstarszych towarzystw naukowych w Rosji i pierwszej społecznej organizacji w tym kraju. Rok 1765 jest datą założenia zarówno tego towarzystwa, którego członkiem Bołotow został rok później, jak i pisma „Trudy Wolnogo ekonomiczeskogo obszczestwa". Wśród znajomych i współpracowników Bołotowa byli Andriej Nartow, Wasilij Lewszyn, Michaił Chieraskow, Jermił Kostrow, Nikołaj Karamzin, Gawriił Dierżawin i in.

„Sielskij żytel”" wychodził od kwietnia 1778 do marca 1779 roku z częstotliwością tygodniową [Лисовский 1895: 5]. Jego zamknięcie po niespełna roku było spowodowane względami finansowymi, niewystarczającymi dochodami z prenumeraty, która objęła zaledwie sto egzemplarzy. Ukazały się 52 numery, bez wyodrębnienia działów czy rubryk, co stanie się powszechnie stosowanym rozwiązaniem dopiero później, np. w skład czasopisma „Ziemledielczeskij żurnał” wejdą cztery działy: „Rolnictwo" („Земледелие”), „Próby i uwagi” („Опыты и наблюдения”), „Wyciągi z czasopism” („Выписка их журналов”) oraz „Korespondencja Towarzystwa” („Переписка Общества"). Ostatni numer - z notką Bołotowa, w której żegnał się on z czytelnikami - nosił datę 30 marca 1779 roku. Miejscem druku była Typografia Uniwersytetu Moskiewskiego (założona w 1756 roku), co zostało odnotowane na stronie tytułowej periodyku. Z propozycją wydania następnego tytułu, będącego kontynuacją poprzedniego, wystąpił Nikołaj Nowikow, wówczas nowy najemca drukarni uniwersyteckiej i wydawca gazety "Moskowskije wiedomosti” („Московские ведомости”). „Ekonomiczeskij magazin” wychodził jako dodatek do tej gazety. O tym, że stanowi on kontynuację tygodnika „Sielskij żytel'”, Bołotow pisał we wstępie do jego pierwszego numeru [Болотов 1780: 3].

Odpowiedź na pytanie o tematykę czasopisma "Sielskij żytel'” daje spis treści, oparty na porządku alfabetycznym opublikowanych materiałów. Zastosowanie takiego rozwiązania sprawia, że czytelnicy mogli posługiwać się nim jak encyklopedią, jego poszczególne artykuły odpowiadają jakby hasłom encyklopedycznym. Pod literą " $\mathrm{A}^{\prime \prime}$ znajdujemy więc artykuł o ",angielskich trawach" i ich zasiewie, pod "B” (, 5 ”) - o błotach i ich osuszaniu, pod „W"

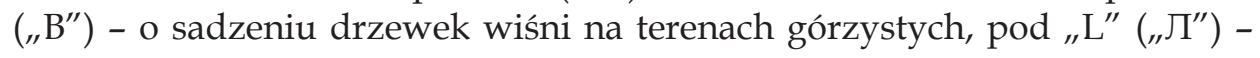


o domowym lekarstwie na przeziębienie, pod „M" - artykuły o malinach i mokradłach, pod „ $\mathrm{R}^{\prime \prime}\left({ } \mathrm{P}^{\prime \prime}\right)$ - o hodowli ryb w stawach, pod „ $\mathrm{T}^{\prime}$ - o tulipanach itp. Wszystkie przykłady pochodzą z pierwszej części pisma. W następnej części mowa jest o wściekliźnie u psów i leczeniu ugryzień przez nie u ludzi oraz innych psów, przechowywaniu grzybów zimą, sadzeniu drzew latem, sposobach pozbycia się myszy, ziołach i leczeniu nimi chorób; charakteryzowane są poszczególne gatunki zbóż, kwiatów, krzewów i drzew (żyto, róża, rumianek, jabłoń i in.). To znów tylko przykłady podjętych tematów. Jak widać, Bołotow, spod pióra którego wyszła większość zamieszczonych pozycji, poruszał problemy także z zakresu medycyny oraz medycyny weterynaryjnej, ziołolecznictwa, żywienia człowieka i zachowania urody, chociaż przeważają prace o uprawie roli i sadownictwie oraz hodowli zwierząt. Bołotow przyczynił się do upowszechnienia w Rosji upraw pomidora i kartofla, przy czym pomidor zmienił swój status z rośliny dekoracyjnej na użytkową [Бердышев 1988a: 154-155]. Repertuar tematów podejmowanych przez uczonego okaże się jeszcze szerszy, jeżeli sięgniemy po pozycje z okresu poprzedzającego wydanie pisma "Sielskij żytel” oraz z lat następnych. Powstanie tego tygodnika przypadło na czwarty okres (z siedmiu wyodrębnionych przez Aleksandra Berdyszewa) w życiu Bołotowa, obejmujący lata 1774-1780 [Бердышев 1988a]. Pozostałe okresy obejmowały lata 1738-1754 (dzieciństwo), 1755-1762 (służba wojskowa), 1762-1774 (pobyt w Dworianinowie), 1780-1790 (propagowanie nauki), 1790-1796 (prace z zakresu pomologii), 1797-1833 (ponowny pobyt w Dworianinowie); lata 1774-1780 zostały nazwane okresem zarządzania majątkami carskimi [Бердышев 1988a]. „W 1766 roku pojawia się pierwsza publikacja Bołotowa w [piśmie - M.D.] «Trudy Wolnogo ekonomiczeskogo obszczestwa» - obszerny (...) przegląd społeczno-ekonomiczny Opis właściwości i walorów gleb powiatu kaszyrskiego, (...) w 1768 - Uwagi o uprawie zbóż w ogólności itd.; łącznie opublikował on [tutaj - M.D.] 28 artykułów" - przypominał Aleksandr I. Akopow [Акопов 1986: 90]. W czasopiśmie „Ziemledielczeskij żurnał” zamieścił 11 prac (z czego 9 w dziale „Próby i obserwacje” i 2 w dziale „Rolnictwo”), poświęconych hodowli bydła, stawom i innym zbiornikom wodnym, żytu, głogowi oraz jabłoniom i innym drzewom owocowym; jeden artykuł ma charakter polemiczny, niektóre są opatrzone rysunkami [por. Соколинский 2006: 38-60]. Do problemów najszerzej rozpatrywanych przez Bołotowa w różnych okresach działalności (w szczególności dworianinowskim) należały gatunki jabłek i gruszek [Соколинский 1900]. Zainteresowania i poglądy Bołotowa można omawiać w kontekście wiedzy agrarnej w Wielkiej Brytanii oraz mających związki z tym krajem uczonych rosyjskich [Kpocc 1996: 104].

"Sielskij żytel" opiera się na rozpowszechnionej w czasach Oświecenia formie dialogu (korespondencji) wydawcy z czytelnikami, przy czym zarów- 
no za "głosami” czytelników, jak i „głosem" wydawcy krył się sam Bołotow. Z przedmowy otwierającej jego pierwszy numer odbiorcy mieli wynieść jednak przekonanie, iż jest to korespondencja autentyczna [Болотов -1778: б.H.c.], a utwierdzić się w nim mieli po lekturze wstępu do czasopisma „Ekonomiczeskij magazin”, którego przedostatni akapit rozpoczynał się od słów: „W czasie wydawania mojego poprzedniego tygodnika pisało do mnie wiele osób z różnych, nierzadko bardzo oddalonych miejsc..." [Болотов 1780: 12]. Korespondenci Bołotowa noszą nazwiska znaczące, wskazujące jednak nie tylko na ich główną cechę, ale i na zainteresowania oraz temat poruszany w liście. Znaleźli się wśród nich więc Nieudaczyn, Woproszalin, Liubopytowa oraz Chlebopachariew, Ługoliubow, Sadoliubow, Malinin, Prostudin. Przykłady można mnożyć. Na odnotowanie zasługuje list podpisany „nie chiński, lecz miejscowy ziemianin”, poświęcony pielęgnacji jabłoni ${ }^{1}$. W części listów pojawia się oznaczenie czasu i miejsca ich napisania. Łatwo domyślić się, że przedmiotem zainteresowania Liubopytowej - jedynej kobiety w gronie korespondentów - były środki pielęgnacji urody ${ }^{2}$. Kilku korespondentów Bołotow wymienił we wstępie do pisma „Ekonomiczeskij magazin”; był to m.in. Czistosierdcow, jeśli wybrać nazwisko szczególnie charakterystyczne dla epoki [Болотов - ч. 1, л. 22, 1778: б.н.c]. Posługiwanie się nazwiskami znaczącymi było rozwiązaniem szeroko stosowanym wtedy $\mathrm{w}$ literaturze

\footnotetext{
${ }^{1}$ Oto początkowe - tworzące ramę całości - partie pytania „miejscowego ziemianina” i odpowiedzi wydawcy:

„Господин Сельский Житель!

Читая ваши листочки, нахожу полезное между прочим изъяснение в 10 листе о размножении и прививании яблоней. [...] Имею честь представить вам некоторое из опытов о истреблении на оных яблонях разного рода червей [...].

Ответ: [...] Упражняясь несколько лет с садами и в разных примечаниях и опытах к ним относящихся, неоднократно случилось мне приметить, что черви, поядающие лист на яблонях, не всегда бывают одинакого рода..." [Болотов - ч. 2, л. 32, 1778: 81, 84].

${ }^{2}$ Oto fragmenty listu czytelniczki i odpowiedzi wydawcy, tym razem z ich środkową merytoryczną - częścią:

„Второе письмо [...] следующего содержания:

Вы помните, что я женщина, и не способна быть экономическую писательницу. [...] А потому и теперешним примечанием служу [...] одним нашим сестрам, сельским домостроительницам, да и то не всем, а только таким, которые того не знают, оно есть следующее. Всем нашим сестрам [...] есть надобность в хорошей мягкой помаде. Теперь о тех мне нечего говорить, которые живут в больших городах, и люди знатные. Сии могут помады для себя всегда купить французские. [...] Все дело в том состоит, чтоб взять свежего свиного сала $[\ldots]$, намочив в чистой воде дать мокнуть 12 суток... [...]

Ответ: [...] Помада, сим образом делаема, в самом деле хороша, но в ней будет не доставать того прекрасного духу, который имеет французская. [...] Нужно только однажды запастись какими нибудь духовитыми маслами, купить их по скляночке в аптеке" [Болотов - ч. 1, л. 22, 1788: б.н.c]. W tego rodzaju receptury i porady obfitowały czasopisma dla kobiet i czasopisma medyczne [Dąbrowska 2016: 259-272].
} 
pięknej, głównie prozie i komedii. Z drugiej strony jednak, należy pamiętać o rzeczywistej korespondencji Bołotowa i jego osobistych kontaktach ze znaczącymi postaciami jego czasów, jak chociażby z członkiem rodu przedsiębiorców uralskich Nikitą (Akinfijewiczem) Demidowem [Самарин 2015: 72-73].

Poza stworzeniem iluzji autentyczności publikowanych listów w przedmowie do pisma "Sielskij żytel'” Bołotow sprecyzował krąg jego odbiorców (mieszkańcy wsi) i częstotliwość wychodzenia (co sobotę). Tekstów programowych, dopełniających przedmowę, znajdujemy w tygodniku więcej. Z perspektywy badań prasohistorycznych szczególnie interesujący wydaje się artykuł z pierwszego numeru z 1778 roku, w którym mowa jest o prawdziwym zalewie - by nie rzec, nomen omen - „urodzaju” nowych czasopism, często noszących nieadekwatne do treści tytuły i wychodzących przez bardzo krótki czas; taki stan rzeczy na współczesnym rynku czasopiśmienniczym skłania do postawienia pytań, jaką pozycję zajmie na nim „Sielskij żytel'” i co nowego wobec tej wielości wniesie on do niego ${ }^{3} \mathrm{~W}$ dalszej części artykułu Bołotow - uzasadniając cel wydawania swojego pisma - przypomina „Trudy Wolnogo ekonomiczeskogo obszczestwa" oraz przeprowadza klasyfikację potencjalnych czytelników (a pośrednio także - skoro ma się ono opierać na korespondencji z nimi - autorów publikowanych materiałów i ich tematyki) ${ }^{4}$. Do tej ostatniej kwestii powróci jeszcze co najmniej dwukrotnie [Болотов - ч. 1, л. 24, 1778: б.н.с; Болотов - ч. 1, л. 26, 1778: б.н.с]. We wszystkich tych arty-

\footnotetext{
3 „Что это за еженедельные сочинения! [...] и будет ли когда конец оным? Нет такого года, в который бы публика не отягощена была ими, а иногда, когда мало одного, так двумя, или тремя. Уже каких и каких мы в немногие сии годы не видали? И всякие-то всячины были и поденщины-то и то-и-сио и ни-то ни-сио, и адские-то почты и трутни-то и живописцы-то, и кошельки-то и Бог знает какие. В одних именах мы истинно уже запутались, а о материях и говорить нечего. Господа сочинители как ни умничают, и как по примеру хамелеонов ни переменяют наружного своего вида и колера, но как-то все худой успех имеют. Почему и не удивительно, что не многие из них могли труды свои года два продолжать; а большая часть сочинений их с нуждою год прожили, а иные в самом своем младенчестве погасли; и об них ни слуху ни духу послушания уже нет" [Болотов - ч. 1, л. 1, 1778: б.н.c]. Mowa jest tu o głośnych czasopismach satyrycznych Nowikowa („Трутень”, 1769-1770; „ЖЖивописец”, 1772; „Кошелек”, 1774) oraz otwierającym dzieje tego typu periodyków tytule założonym z inicjatywy Katarzyny II („Всякая всячина”, 1769), a także o pismach z 1769 roku Wasilija Tuzowa („Поденщина”), Michaiła Czułowa („И то и сио”), Wasilija Rubana („Ни то ни сио”) i Fiodora Emina („Адская почта”).

4 „Основательные сочинения нашего Вольного экономического общества нам довольно доказали, сколь много у нас до таких сочинений охотников. Большая часть деревенских жителей и не знают еще о том, что они есть на свете, несмотря, что они для пользы их пишутся..." [Болотов - ч. 1, л. 1, 1778: б.н.с.]. Najważniejsze grupy czytelników tworzą, zdaniem Bołotowa, osoby zainteresowane uprawą zboża (grupa pierwsza) oraz sianokosami, leśnictwem i wykorzystaniem stawów (druga), a także ogrodnicy i sadownicy (trzecia).
} 
kułach, a także w artykule otwierającym drugą część pisma [Болотов - ч. 2, л. 1, 1778: б.н.c], przekonywał on o użyteczności swego periodyku, praktycznej wartości przekazywanych w nim treści. „Pożytek” należy do słów kluczowych pisma Bołotowa i całej formacji oświeceniowej.

Czasopismo „Sielskij żytel'” jawi się jako ważne ogniwo procesu historycznoprasowego w Rosji drugiej połowy XVIII wieku oraz jedno z głównych źródeł informacji o ówczesnym stanie wiedzy z zakresu agronomii. Zestawienie jego zawartości z mającymi podobny profil czasopismami zachodnioeuropejskimi oraz innymi dokumentami dotyczącymi kultury agrarnej w oświeceniowej Europie pozwoli odpowiedzieć na pytanie, na ile Rosja dotrzymywała kroku w tej dziedzinie pozostałej części kontynentu, a na ile pozostawała $w$ tyle, a także na ile zachowywała odrębność $w$ tej dziedzinie, a na ile wpisywała się w ogólne nurty rozwojowe. Dla porównania warto dodać, że początki polskiego czasopiśmiennictwa rolniczego sięgają „Nowych Wiadomości Ekonomicznych i Uczonych” W. Mitzlera de Koloff z 1758 roku [Lipski 1976: 53]. W odniesieniu do sztuki ogrodowej częściowo dały odpowiedź na to pytanie wstępne rozważania o Hirschfeldzie. W czasopiśmie Bołotowa nie sposób nie dostrzec jednak słabych stron, które w taki oto sposób - pośrednio nawiązując do wspomnianego zachodnioeuropejskiego kontekstu interpretacyjnego - określił Berdyszew: „drukowany na złym papierze słabo przyciągał uwage, był pozbawiony ciągłej numeracji stron i tytułów artykułów, co utrudniało szybkie znalezienie potrzebnego materiału, ale za to zawartości mogło pozazdrościć mu wiele zagranicznych czasopism tego okresu - wystarczy powiedzieć, że tylko w pierwszej części pisma zostały opublikowane artykuły zawierające ważne odkrycia naukowe" (do takich badacz zaliczył prace o łąkach i jabłoniach) [Бердышев 1988a: 152153]. Jeżeli chodzi zaś o całokształt spuścizny Bołotowa, to wyróżnia się ona obszernością i różnorodnością. Bierdnikow i Sieriebrianyj pisali:

[...] dorobek Bołotowa - jednego z najbardziej płodnych pisarzy Rosji - liczy przypuszczalnie około trzystu pięćdziesięciu tomów [...] materiałów: wspomnień, dzienników, listów, wierszy, sztuk, artykułów krytycznych, przekładów, a także wiele prac z zakresu literatury, filozofii, teologii, wychowania, [...] agronomii i historii, spośród których tylko nieliczne ujrzały światło dzienne [Бердников, Серебряный 2002: 37].

Liczba tych, które zostały udostępnione czytelnikom, stale rośnie, niemniej wiele $\mathrm{w}$ tej dziedzinie - a także, rzecz oczywista, w zakresie wszechstronnego zinterpretowania Bołotowowskiej spuścizny - pozostało jeszcze do zrobienia. Dlatego nie dziwi fakt, że słowa ",z niewydanego dorobku” mają w swoich tytułach albo we wstępnych partiach opracowania wydane zarówno wiele dziesięcioleci temu [Морозов, Кучеров 1933: 153-190], jak i całkiem niedawno [Веселова 1999: 358-367]. 


\section{Bibliografia}

Акопов А. Т. 1986. Отечественные специильные журналы 1765-1917. Историко-типологический обзор, Ростов-на-Дону: Издательство Ростовского университета.

Антонова В., Губина А. Б., Строкина В. Н. (red.) 1990. А. Т. Болотов в Кенигсберге. Из записок А. Т. Болотова, написанных самим им для своих потомков, Калининград: Калининградское книжное издательство.

Бердников Л., Серебряный Ю. 2002. Пантеон российских писателей XVIII века. Критико-биографические очерки, Санкт-Петербург: Академический Проект.

Бердышев А. П. 1949. Андрей Тимофеевич Болотов. Первый русский ученый-агромом, Москва: Госсельхозиздат.

Бердышев А. П. 1988а. Андрей Тимофеевич Болотов - выдающииися деятель науки и культуры. 1738-1833, Москва: Издательство „Наука”.

Бердышев А. П. 1988б. Андрей Тимофеевич Болотов - основоположник русской сельско-хозяйственной науки. 1738-1833, Москва: АГРОПРОМИЗДАТ.

[Болотов А. Т.] 1778. Известие в уведомление тех, кои не получали сие издание еженедельно, и объяснение об оном не читали, сообщается следующее..., „Сельский житель”, сz. 1, nr 1.

[Болотов А. Т.] 1778. [Как за несколько времени...], „Сельский житель”, сz. 1, nr 24, 15 września.

[Болотов А. Т.] 1778. [Как наиглавнейшим предметом желаний...], „Сельский житель”, cz. 1, nr 22, 1 września.

[Болотов А. Т.] 1778. [Сей ^исток последний из тех...], „Сельский житель”, cz. 1, nr 26, 29 września.

[Болотов А. Т.] 1778. [Читая ващи мисточки...], „Сельский житель”, сz. 2, nr 32, 10 listopada, s. 81-84.

[Болотов А. Т.] 1778. [Я не сомневаюсь...], „Сельский житель”, cz. 1, nr 1, 7 września.

[Болотов А. Т.] 1779. Известие, „Сельский житель”, cz. 2, nr 1.

[Болотов А. Т.] 1780. Вступление, „Экономический магазин”, cz. 1, nr 1, s. 3-16.

Болотов А. Т. 1803. [Описание используемых в хозяйстве полезных изобретении]], „Записки деяний Императорского Вольного экономического общества", s. 22-28.

Болотов А. Т. 1822. Опытные замечания, относящиеся к скотоводству, „Земледельческий журнал", nr 4, s. 109-113.

Болотов А. Т. 1993. Избранное, Псков: Издательство ПОИПКРО.

Веселова А. Ю. 1999. Из наследия А. Е. Болотова: статья „О пользе, происходящей от чтения книг", „XVIII век”, t. 21, s. 358-367.

Веселова А. Ю. 2002. А. Т. Болотов и П. З. Хомяков. Роман или мемуары?, „XVIII век”, t. 22, s. 190-199.

Веселова А. Ю. 2008. Еще раз о русских переводах английских садоводческих трактатов, [w:] Н. Д. Кочеткова (red.) „XVIII век”, t. 25, Санкт-Петербург: Наука, s. 333-345.

Демиховский А. К. 1993. А. Т. Болотов - поэт и философ природы, [в:] А. Т. Болотов, Избранное, Псков: Издательство ПОИПКРО, s. 125-132.

Кудрявцева Е. Б. 2010. Для сердияа и разума. Детская литература в России XVIII В., Санкт-Петербург: Издательство „Нестор-История”.

Кросс Э. 1996. У темзских берегов. Россияне в Британии в XVIII веке, перевод Н. Л. Лужецкая, Санкт-Петербург: Гуманитарное агентство „Академический проект”. 
Лазарев В. 1979. „Жизнь и приключения Андрея Болотова...”, [w:] Е. И. Осетров (red.), Встречи с книгой, Москва: Книга, s. 130-147.

Лазарчук Р. М. 1988. Болотов Андрей Тимофеевич, [w:] Словарь русских писателей XVIII века, вып. 1 (А-И), Ленинград: Наука, s. 114-117.

Лисовский Н. М. 1895. Русская периодическая печать 1703-1894 г2. (Библиографрия и графические таблицы), t. 1, Санкт-Петербург.

Любченко О. Н. 1988. Андрей Тимофееъич Болотов, Тула: Приокское книжное издательство.

Морозов И., Кучеров А. 1933. Из неизданного литературного наследия Болотова, „Литературное наследство", t. 9-10, Москва: Журнально-Газетное Объединение, s. 153-190.

Ольшевская Л. А., Травников С. Н. 2002. Болотов Андрей Тимофеевич, [w:] С. А. Джанумов (red.), Русские писатели. XVIII век. Биобиблиографический словарь, Москва: Просвещение.

Плодоводство в России. Материалы и исследования, t. 3 (Изображения и описания разных пород яблок и груш, родящихся $в$ Дворениновских, а отчасти и в других садах. Рисованы и описаны Андреем Болотовым В Дворенинове с 1797 по 1801 год. Издание из рукописи под вышеприведенным заглавием, составленное А. С. Гребнициким), Санкт-Петербург 1900.

Самарин А. Ю. 2015. Типографщики и книгочёты. Очерки по истории книги в России второй половины XVIII века, wуd. 2, Москва: Пашков дом.

Семевский М. 1870 [bez tytułu], [w:] Жизнь и приключения Андрея Болотова описанные им самим для своих потомков. 1738-1793. Приложение к „Русской старине”, wyd. 2, t. 1, [bez miejsca], s. III-X.

Соколинский Е. К. (red.) 2006. Сводный каталог сериальных изданий России (1801-1825), t. 3 - Журналы (3-М). С росписью содержания, Санкт-Петербург: Российская национальная библиотека.

Dąbrowska M. 2016. Tematyka medyczna w czasopismach rosyjskich przełomu XVIII $i$ XIX wieku, [w:] J. Dzieniakowska, M. Olczak-Kardas (red.), Książka. Biblioteka. Informacja. Między podziałami a wspólnota V, Kielce: Uniwersytet Jana Kochanowskiego, s. 259-272.

Lichaczow D. 1991. Poezja ogrodów. O semantyce stylów ogrodowo-parkowych, przeł. K. N. Sakowicz, Wrocław-Warszawa-Kraków: Zakład Narodowy imienia Ossolińskich.

Lipski W. 1976. Czasopisma rolnicze, [w:] J. Maślanka (red.), Encyklopedia wiedzy o prasie, Wrocław-Warszawa-Kraków-Gdańsk: Zakład Narodowy im. Ossolińskich, s. 52-53. 